\title{
GROWTH AND AGE \\ IN THE \\ GIANT TORTOISE OF THE GALAPAGOS
}

\author{
By Charles Haskins Townsend
}

Director of the New York Aquarium

(Figs. 357-369 incl.)

The tortoises brought from the Galapagos Islands in 1928 under the auspices of the New York Zoological Society, were located in small colonies at several points near the southern boundary of the United States, and also in the Bermuda and Hawaiian Islands. All are of the same species, Testudo vicina.

The object in view was their propagation under various climatic conditions supposed to be favorable. Tortoises from the Galapagos, mostly specimens of large size, had long been kept in zoological gardens in Europe and in our northern states, where being housed for many months in winter and otherwise confined, they had never bred.

During a period of more than three centuries, tortoises were taken from the Galapagos Islands in great numbers to be used as food on vessels cruising in that part of the Pacific Ocean. By the end of the nineteenth century they had disappeared from most of the smaller islands of the group and from the coastal regions of the larger islands. It was known that the introduction of dogs, pigs, cats and rats by settlers on the Galapagos, had caused the destruction of eggs and newly-hatched young of the tortoises so that there was little or no increase. The settlers have been eating them for a hundred years and continue to do so.

Learning that tortoises were probably obtainable in the mountains of Albemarle the largest of the islands, the writer was authorized to secure if possible, specimens for propagation elsewhere. The number secured being much greater than was expected, they were distributed more widely than was originally intended, with the result that some localities proved to be less favorable for this tropical animal than others. 
It was therefore found desirable to transfer many of the tortoises located in the southwestern states to southern Florida, where housing in winter seems to be unnecessary. Although occasional frosts occur at three of the four stations in southern Florida, one colony is located at Lignum Vitae among the islands farther south, entirely beyond any record of frost. The colonies in Bermuda and Hawaii are well placed. The tortoises composing them have made rapid growth and have suffered no losses in numbers. The Bermuda colony of ten young tortoises having a total weight of sixty-six pounds in 1928, now (1930) weighs 175 pounds. The colony of six larger tortoises at Honolulu weighing 159 pounds in 1929, has at present (1930) a total weight of 378 pounds. ${ }^{1}$

The growth made by tortoises located in the southern states has been as follows:

\begin{tabular}{lccccc}
\multicolumn{1}{c}{ Place } & $\begin{array}{c}\text { Number } \\
\text { of tortoises }\end{array}$ & Average & Total lbs. & Total lbs. & Increase \\
Brighton, Fla. & 5 & 7 & 1928 & 1930 & $(\%)$ \\
Opa-Locka, Fla. & 5 & 8 & 35 & 135 & 286 \\
Biscayne Is., Fla. & 18 & 18 & 334 & 127 & 202 \\
Lignum Vitae Is., Fla. & 8 & 31 & 248 & 502 & 80 \\
New Orleans, La. & 7 & 14 & 100 & 286 & 186 \\
Houston, Texas & 14 & 13 & 192 & 709 & 269 \\
San Antonio, Texas & 8 & 14 & 111 & 316 & 185 \\
Superior, Ariz. & 3 & 23 & 71 & .118 & 66 \\
San Diego, Calif. & 19 & 25 & 479 & 1041 & 117
\end{tabular}

An examination of the above table shows an uneven rate of growth, which requires explanation. The conditions contributing to the results attained are traceable chiefly to climate and method of treatment. The tortoises located in the southern states outside of Florida, were with one exception kept on grassy ranges in zoological gardens, where in addition to grazing they had a variety of garden vegetables.

At Superior, Arizona, the tortoises had the range of a cactus grove in the Southwestern Arboretum and subsisted chiefly on the abundant prickly pears, very little other food being provided.

Coming from an equatorial island, and lacking the protection of either fur or feathers, it was soon discovered that these cold blooded animals required protection in winter at all of these places.

1 On March 31, 1931, the weight of the Honolulu colony had increased to 434 pounds. 
Although at first provided with accessible shelters the tortoises did not always seek them at night, with the result that there were early losses at some localities before complete winter housing was arranged for. Portions of these colonies have been removed to the milder climate of southern Florida. While protection in winter has proven a safeguard for those left at the original stations, this practice may not be favorable to reproduction. It is apparent that the best conditions for growth and increase in numbers cannot be expected within the limits of the United States, except in southern Florida.

At Lignum Vitae Island in latitude $25^{\circ}$, well below the frost line, the tortoises have subsisted entirely on the numerous kinds of grasses found there. The moderate growth so attained is assumed to be normal. It has been stimulated among those located in zoological gardens where regular feeding of vegetables in addition to grazing was practiced.

Reports on the colony of tortoises presented to the Zoological Society of Sydney, Australia, have not yet been received.

The most important record of growth within our borders is that of a Galapagos tortoise kept at Riverside in one of the interior valleys of southern California. This tortoise (Fig. 357) weighing twenty-nine pounds in 1899 , reached a weight of 350 pounds in seven years, or nearly twelve times the earlier weight. Its later growth was slower as it gained only sixty-five pounds during the next seven years. This animal was kept summer and winter in a yard sixty feet square and provided with a small shed which it habitually sought for shelter. There was no opportunity for grazing but it must have been well fed. Because of the presence of a cow, the trampled yard became muddy in winter. The tortoise died in 1914 (Fig. 357). Mr. Edmund Heller, to whom it belonged, says that if it had been kept on dry ground it would probably be alive today. It attained large size while young but unfavorable conditions account in part for the limited growth made during the latter part of its life. Large tortoises grow slowly; the young rapidly.

Climatic conditions at Riverside are apparently more favorable than at San Diego, located on the coast in the same State and frequently exposed to chilly sea winds and at times to frosty weather. Post-mortem examinations show that the losses here were from enteritis, the well-fed tortoises failing to seek shelter after the day's grazing, were too cold at night for digestion to proceed. 
A Galapagos tortoise (T. vicina) a male weighing 140 pounds was received at the New York Zoological Park in 1904. During the next twenty-five years its growth was slow, the present weight being but 305 pounds. (Fig. 358). Its condition is similar to that of other Galapagos tortoises confined within doors during more than half of the year. Its plates are worn smooth, due apparently to the habit the tortoises have of crawling over each other in moving about the pen. Its rings cannot now be counted. It has never had a mate. The growth of several very young tortoises (T. vicina) still retained at the New York Zoological Park, has been negligible as compared with those located in the South. Although most comfortably housed in winter, they have not had the advantage of grazing in summer which we now know is conducive to rapid growth. This defect in treatment will doubtless be corrected with the return of summer.

The following shows the character of the records being kept at each locality where tortoises have been placed:

\begin{tabular}{|c|c|c|c|c|c|c|c|c|}
\hline \multirow[b]{2}{*}{ No. } & \multicolumn{2}{|c|}{ LENGTH } & \multicolumn{2}{|c|}{ WIDTH } & \multirow[b]{2}{*}{ Height } & \multirow{2}{*}{$\begin{array}{c}\text { wt. lbs. } \\
\text { June } 18 \\
1928\end{array}$} & \multirow{2}{*}{$\begin{array}{c}\text { wt. lbs. } \\
\text { Mar. } 8 \\
1929\end{array}$} & \multirow{2}{*}{$\begin{array}{c}\text { wt. lbs. } \\
\text { July } 11 \\
1930\end{array}$} \\
\hline & Straight & Curved & Straight & Curved & & & & \\
\hline 90 & $131 / 8$ & $171 / 2$ & 11 & $171 / 4$ & $71 / 4$ & $133 / 4$ & 21 & 44 \\
\hline 91 & $121 / 2$ & $15 \frac{3}{4}$ & $91 / 2$ & $14 \frac{5}{8}$ & $57 / 8$ & 10 & 15 & 39 \\
\hline 92 & $11 \frac{1}{8}$ & $14 \frac{1}{2}$ & $81 / 2$ & $13 \frac{1}{4}$ & $51 / 4$ & 7 & 12 & 35 \\
\hline 93 & 12 & $153 / 4$ & $91 / 4$ & $143 / 4$ & 6 & 8 & $131 / 2$ & 45 \\
\hline 94 & $113 / 4$ & $14 \frac{5}{8}$ & $87 / 8$ & 14 & $5 \frac{5}{8}$ & $77 / 8$ & 16 & 39 \\
\hline 95 & $12 \frac{1}{4}$ & $15 \frac{1}{2}$ & $91 / 2$ & 15 & 6 & 10 & 15 & 40 \\
\hline 96 & $131 / 4$ & $173 / 4$ & $103 / 4$ & $171 / 4$ & $63 / 4$ & 12 & $231 / 2$ & 61 \\
\hline 98 & $103 / 4$ & $13 \frac{1}{2}$ & $81 / 2$ & 13 & $51 / 8$ & $73 / 4$ & 17 & 47 \\
\hline 99 & $12 \frac{1}{2}$ & $153 / 4$ & $95 / 8$ & $15 \frac{1}{4}$ & $61 / 8$ & 10 & 15 & 46 \\
\hline 100 & $115 / 8$ & 15 & $91 / 8$ & $14 \frac{1}{2}$ & $53 / 4$ & 9 & 14 & 47 \\
\hline 101 & 12 & 15 & $61 / 2$ & $143 / 4$ & $57 / 8$ & 8 & 13 & 32 \\
\hline 102 & $111 / 2$ & $135 / 8$ & $83 / 4$ & $131 / 4$ & 5 & 8 & 16 & 28 \\
\hline 103 & $121 / 8$ & $15 \frac{3}{4}$ & 10 & $151 / 2$ & $61 / 2$ & $101 / 4$ & 19 & 40 \\
\hline \multirow[t]{2}{*}{104} & 24 & $293 / 4$ & $181 / 8$ & $293 / 4$ & $12 \frac{1}{4}$ & 71 & 98 & 166 \\
\hline & & & & & & $1925 / 8$ & 308 & 709 \\
\hline
\end{tabular}

This colony is in the Zoological Garden at Houston, Texas. Weighed and measured in the New York Zoological Park before shipment in 1928.

It will be seen that the hope of propagating the giant tortoise is based on conditions involving captivity and control. It would be 
difficult at the present time to liberate tortoises anywhere with expectation of safety for the young. The amazing numbers and great size attained on the Galapagos Islands was the natural result of absence of enemies of the young. Such a condition no longer obtains on those islands where introduced predatory animals now abound.

When the half-grown tortoises now ranging widely on Lignum Vitae Island attain breeding size, they will require the same protection as those located elsewhere under control and will probably be removed. Otherwise, the newly-hatched young would be decimated by the raccoons and other predators abounding there. It is doubtful if more than a very small proportion of the newly-hatched young of any of our native tortoises escape the smaller carnivorous mammals and birds of prey. The larger snakes may also destroy them. The natives say that the Galapagos hawk feeds to some extent on baby tortoises.

The breeding age of the giant tortoise is unknown. Our largest specimens in the South do not weigh more than one hundred pounds. Observations are being made. When mating occurs and the digging of nests is seen, the nests will be closely protected with wire and the tender young removed to safe quarters.

Age.-The age of the giant tortoise while comparatively young seems to be traceable in the striations of the horny plates of its carapace. We have one Galapagos tortoise, No. 190, the age of which is known within a year or two. It was taken to Guayaquil, Ecuador, when "small enough to be clasped in one hand." After "ten years" in that city, it was presented in 1930 to the writer who at once took it to his country home near New York for observation. ${ }^{2}$ Its weight on July 1, was eighty pounds. Established on a grassy range and fed a variety of garden vegetables, its weight increased to ninety-one pounds by September 1, when it was taken to the Zoological Park for the winter. This tortoise, like those in northern Zoological gardens, was entirely black when placed on grass. Within a month, thin white lines of growth appeared around the margins of its plates, as shown in figure 359. By the end of another month the white margins had broadened into very conspicuous bands, as though the plates had been heavily outlined with chalk. This of course was not done. The tortoise then had the appearance shown

${ }^{2}$ Presented by Captain Murphy, Commanding S. S. Buenaventura of the Panama R. R. Steamship Line. 
in figures 360,361 and 362 , the white bands being most pronounced between the costal and marginal plates. This tortoise may be regarded as an example of stimulated growth.

On March 18, 1931, we received a Galapagos tortoise (No. 191, Fig. 363) the age of which is also known. ${ }^{3}$ Taken to Guayaquil when very small it was kept there for "fifteen years." Its weight upon arrival at New York was only eight pounds and its length (curved) of carapace fourteen inches. The very distinct growth rings on its plates number fifteen, corresponding with its reported age. This specimen, three years older than No. 190, but only a tenth of its weight, may have lived under conditions not favorable to growth. With the return of warm weather, it will have treatment similar to that under which tortoise No. 190 so rapidly attained weight.

Measurements of many tortoises show that growth in height is more rapid than growth in length. Assuming that the small smooth area in the center of each plate represents the first year's growth, it is not difficult to count with a lens on most of the plates of tortoise No. 190, eleven rings which seem to represent annual growth, not including the white ring acquired rapidly in 1930. Such counting of rings appears to confirm the statement of the original owner of the tortoise as to its age - now about twelve years. The rings are more readily discernible on the animal itself than in the photographs. In larger and older tortoises the striations tend to flatten out.

An examination of photographs of other tortoises of the same species reveals similar markings. Being of nearly the same size, and having the same number of rings, we assume that they are of about the same age. The large tortoise, No. 104 (Fig. 364) weighed seventy-one pounds when brought from the Galapagos in 1928. Its weight is less than that of No. 190 and it is slightly smaller.

The rings on its plates are fewer in number. Its age may be ten years. The younger tortoises around it have still fewer ringssix to eight. This colony is in Houston, Texas. An eighty-fourpound tortoise (Testudo porteri) was brought from Indefatigable Island, Galapagos, in 1930 by Mr. Vincent Astor. This is No. 187 (Fig. 365). Having about the same number of plate rings as No. 190 (T. vicina), its age should be about twelve years. The large tortoise referred to above (Fig. 357) weighing twenty-nine pounds when

Presented by Mr. Wm. H. C. Castles, Purser of S. S. Buenaventura of the Panama R. R. Steamship Line. 
captured, lived fourteen years in captivity. The rings on its plates seem to be about twenty in number, indicating approximately its age. The counting of such rings, except on very young tortoises, is about as difficult as counting them on the scales of salmon.

The smallest tortoise secured in 1928 (Fig. 366) and now in the New York Zoological Park had, when captured, a length of three and three-eighth inches (carapace) and a weight of three and threefourth ounces. It then had two distinct rings in its plates. Its present length is four and one-half inches and its weight twelve ounces. It has now four rings which seem to indicate its age (Fig. $367)$.

It is not unlikely that the striations of the horny plates have already been considered as indicative of age in Galapagos tortoises, but we have not searched for literature on the subject. Coker has stated that "the markings of the horny scutes of the carapace and plastron compute with approximate certainty the ages of some terrapins of various sizes." 4 He presents reproductions of photographs that well support the statement.

The common supposition that large Galapagos tortoises must be of great age is unwarranted. Under natural conditions and especially under favorable climatic conditions in captivity, they reach a large size in a few years, when the rate of growth becomes slow. There are records of both Galapagos and Aldabra giant tortoises that lived under observation in tropical climates more than 150 years, when their lives ended upon removal to cold climates. The real length of life is unknown. Certain museum specimens known to have exceeded 500 pounds at death, were doubtless very old.

Note on Habits:-While being kept in a grassy yard, tortoise number 190 afforded an opportunity for observations on its habits. About an hour before sunset it headed into some nook or corner where the carapace could be pressed against something solid. The sod was then slowly scratched away until the animal rested with its plastron flat on the raw soil. This practice doubtless safe enough on the well-drained volcanic earth of the Galapagos and possibly there inducive to warmth, could not be allowed on damp ground in the North. Each evening the tortoise was pulled out of its newly made form and driven to a dry shed in the corner of its yard, where

${ }^{4}$ Cultivation of the Diamond-back Terrapin. R. E. Coker. North Carolina Geol. Surv. Bull. 14, 1906. 
it burrowed under some straw. This procedure continued for about two weeks, when the tortoise habituated to the procedure or realizing that there was comfort in the shed, sought its warmth voluntarily. There were but few lapses into its inherited habit of scratching out a form in which to pass the night (Figs. 368-369).

While the giant tortoise pays little attention to ordinary sights and sounds, its sight and hearing cannot be defective. A noise made at the gate when vegetables were brought served to attract it to the spot. It could see a red tomato perhaps at a greater distance than any other vegetable thrown in its direction. It liked grazing on the open lawn. When not too far back in the high-walled yard, it could see the way out when the gate was opened quietly and lost little time in escaping.

\section{ACKNOWLEDGMENTS}

The Zoological Society is indebted to the following named persons coöperating in the attempt to rear the giant tortoise in captivity: Dr. Harry M. Wegeforth, President Zoological Society, San Diego, California; Dr. F. J. Crider, Director Boyce Thompson Southwestern Arboretum, Superior, Arizona; Mr. A. H. Hanson, Superintendent of Parks, San Antonio, Texas; Mr. C. L. Brock, Superintendent of Parks, Houston, Texas; Mr. Marion Weis, President Zoological Society, New Orleans, Louisiana; Mr. James H. Bright, Hialeah, Florida, for facilities afforded in the small zoological gardens at Brighton and Opa-Locka; Mr. Hugh M. Matheson of Coconut Grove, Florida, for similar assistance at his properties on Biscayne and Lignum Vitae islands; Mr. L. L. Mowbray, The Flatts, Bermuda; The Commissioner of Parks, Honolulu, T. H. and the Secretary of the Zoological Garden, Sydney, Australia.

The following members of the Board of Managers of the New York Zoological Society contributed the fund of $\$ 6,000$ which made possible the writer's search for tortoises: Robert S. Brewster, Bayard Dominick, Anson W. Hard, Anthony R. Kuser,* Irving K. Taylor and Henry D. Whiton.* Hon. Henry O'Malley, U. S. Commissioner of Fisheries authorized the use of the U. S. S. Albatross II for the voyage to the Galapagos in 1928.

* Deceased. 


\section{GROWTH AND AGE IN THE \\ GIANT TORTOISE OF THE GALAPAGOS}

Series of Figures 

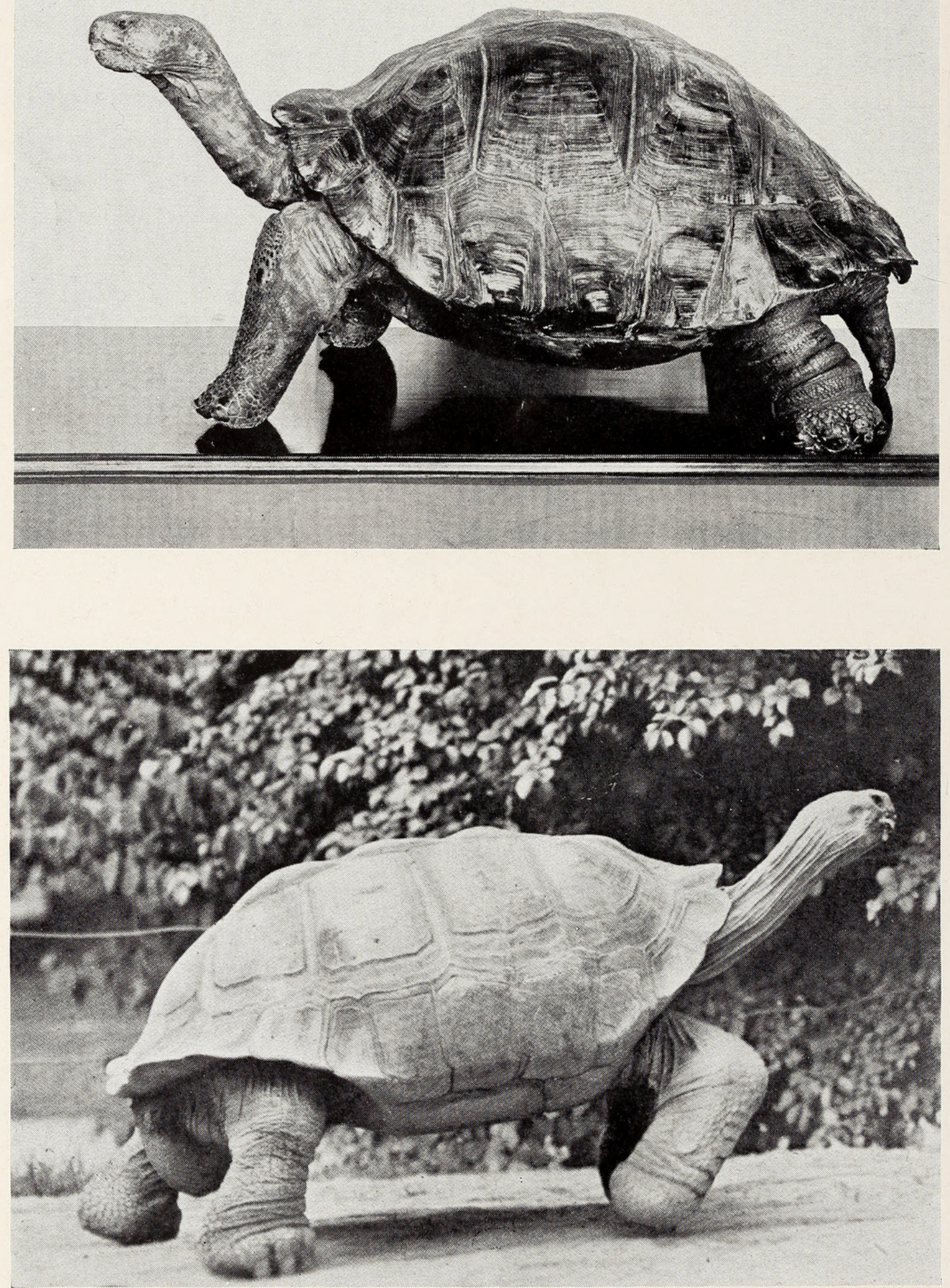

Fig. 357. Upper: Testudo vicina, Albemarle Island, Galapagos. Increased in weight over 300 pounds in seven years. Fig. 358. Lower: Testudo vicina, Albemarle Island, Galapagos. Increased in weight from 140 pounds in 1904, to 305 pounds in 1930 . Kept in the New York Zoological Park. 

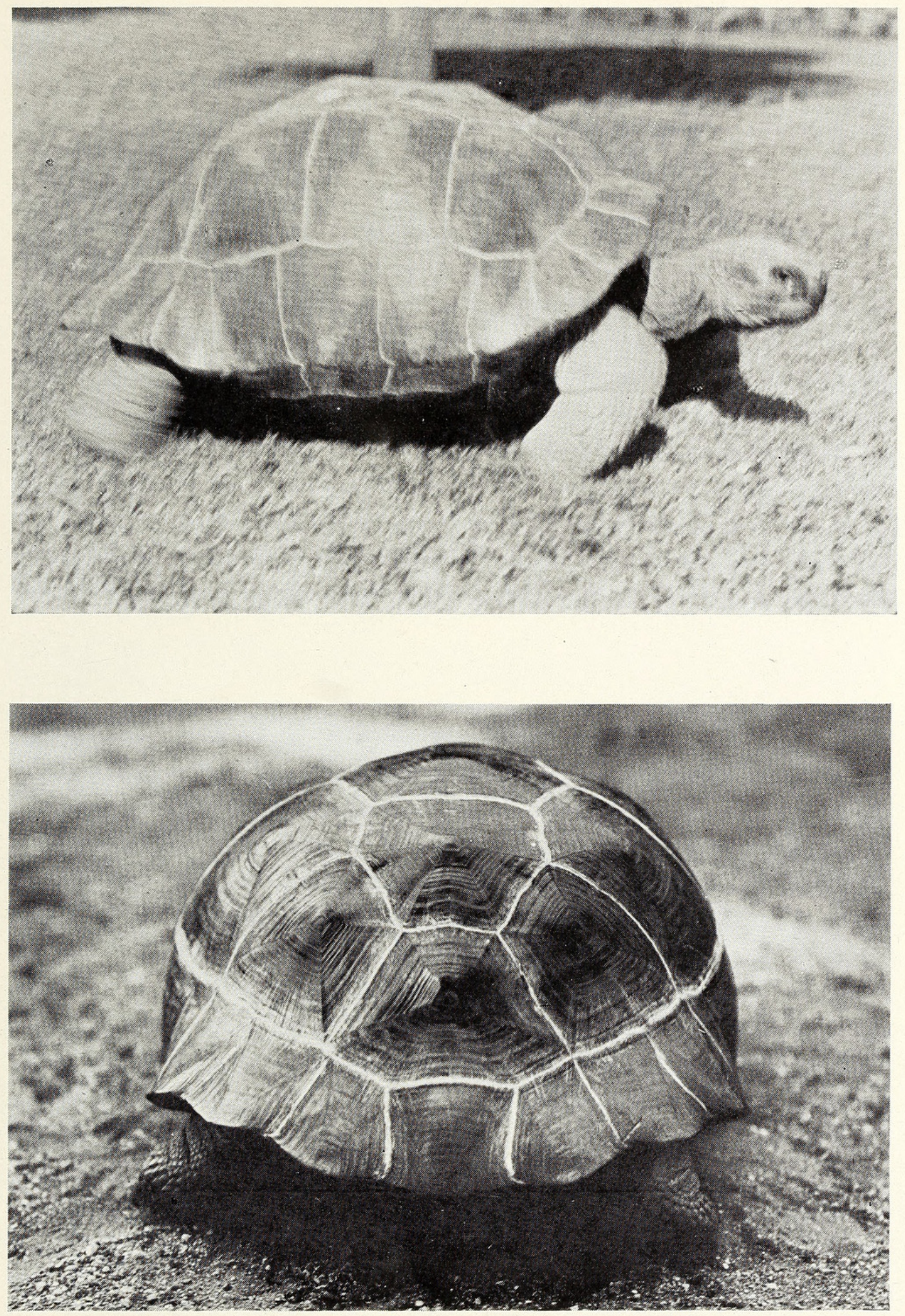

Fig. 359. Upper: Tortoise No. 190. Weight increased from 81 pounds to 91 pounds in two months. White margins of plates beginning to show at the end of first month. Fig. 360. Lower: Tortoise No. 190 after two months on a grassy range. Rings of growth on plates correspond with known age-12 years. 


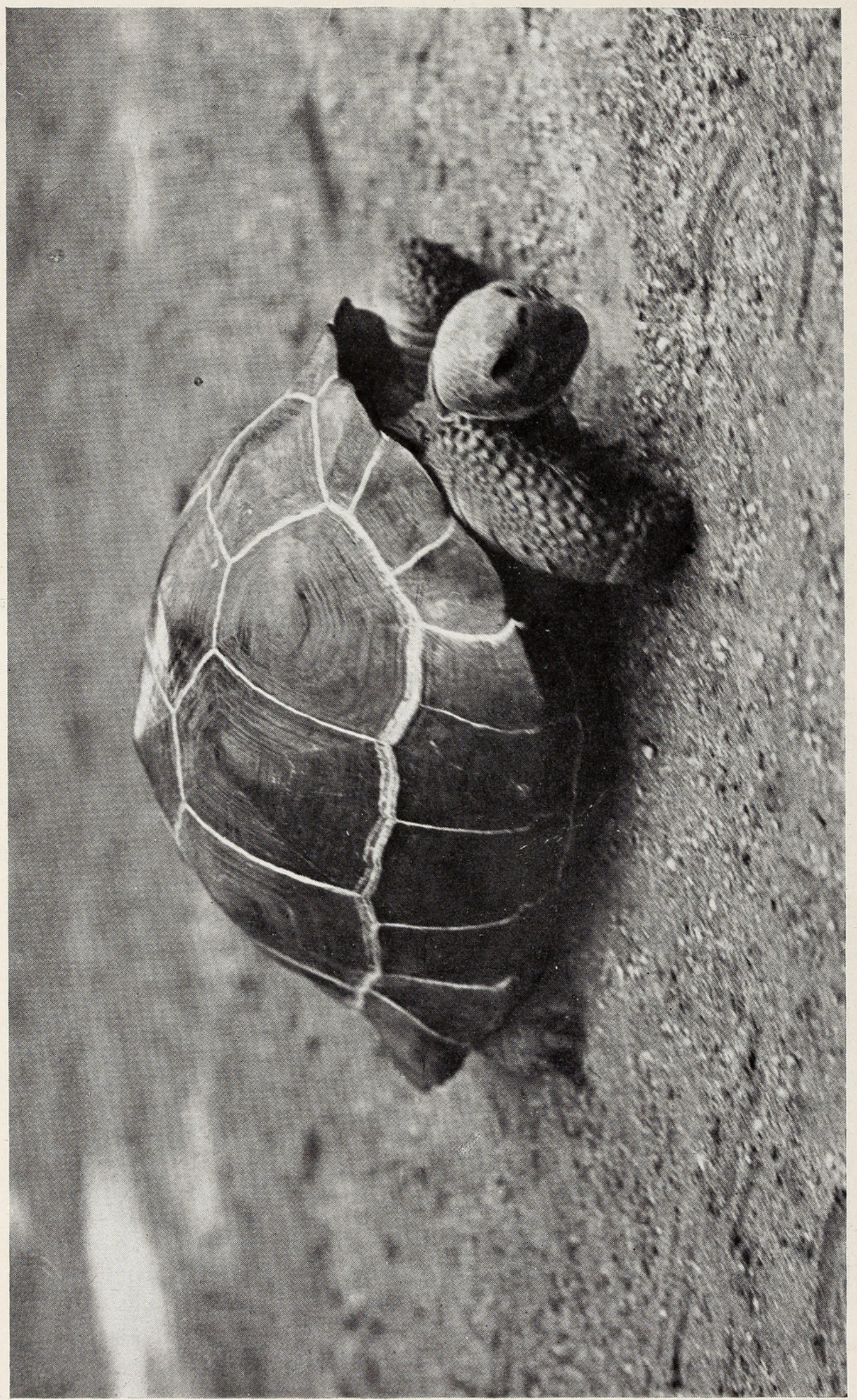



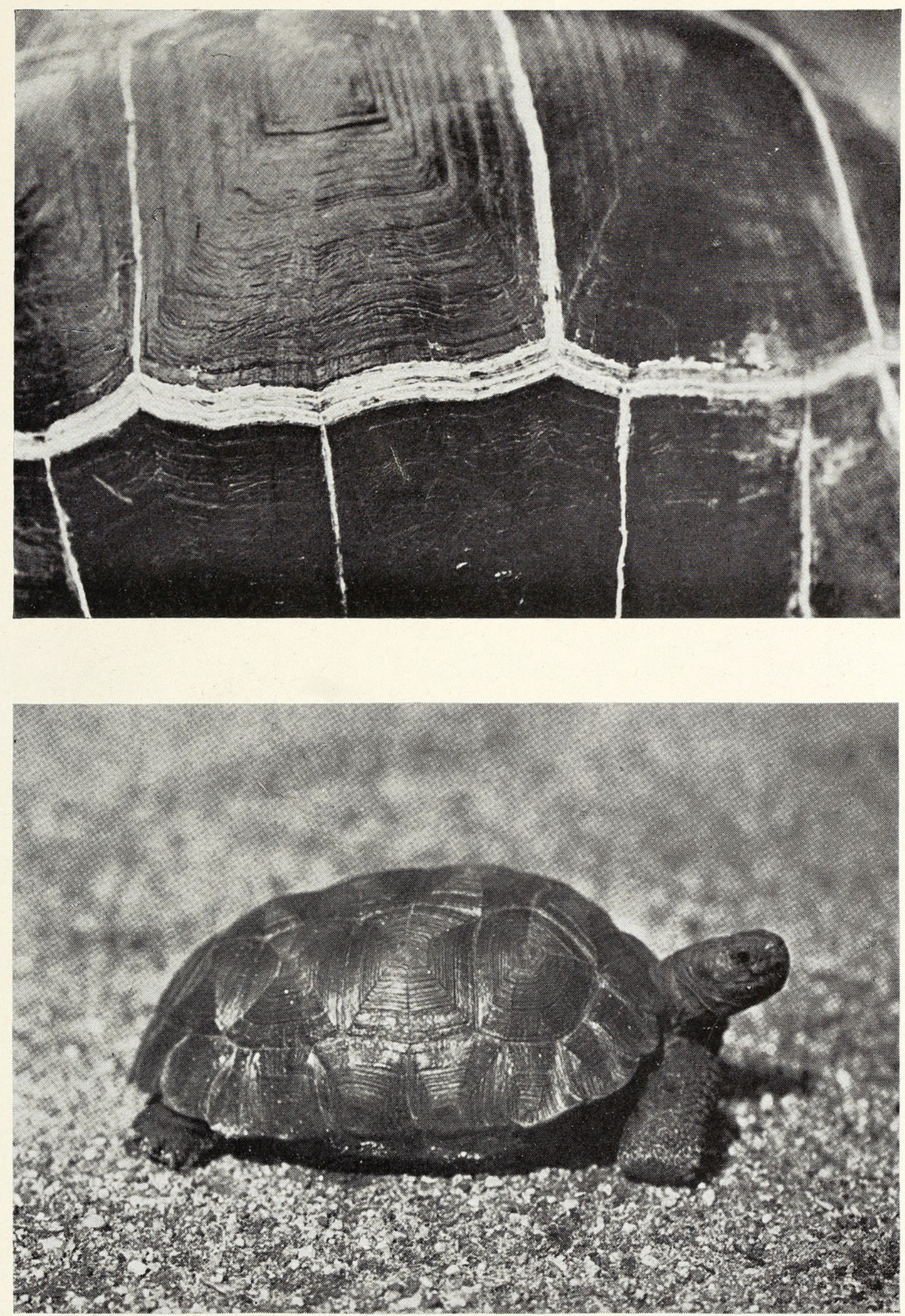

Fig. 362. Upper: Tortoise No. 190 after two months on a grassy range. White skingrowth between costal and marginal plates, one-quarter inch wide. Fig. 363. Lower: Galapagos tortoise, species not known. Raised in Guayaquil Ecuador, reported to be 15 years old. 

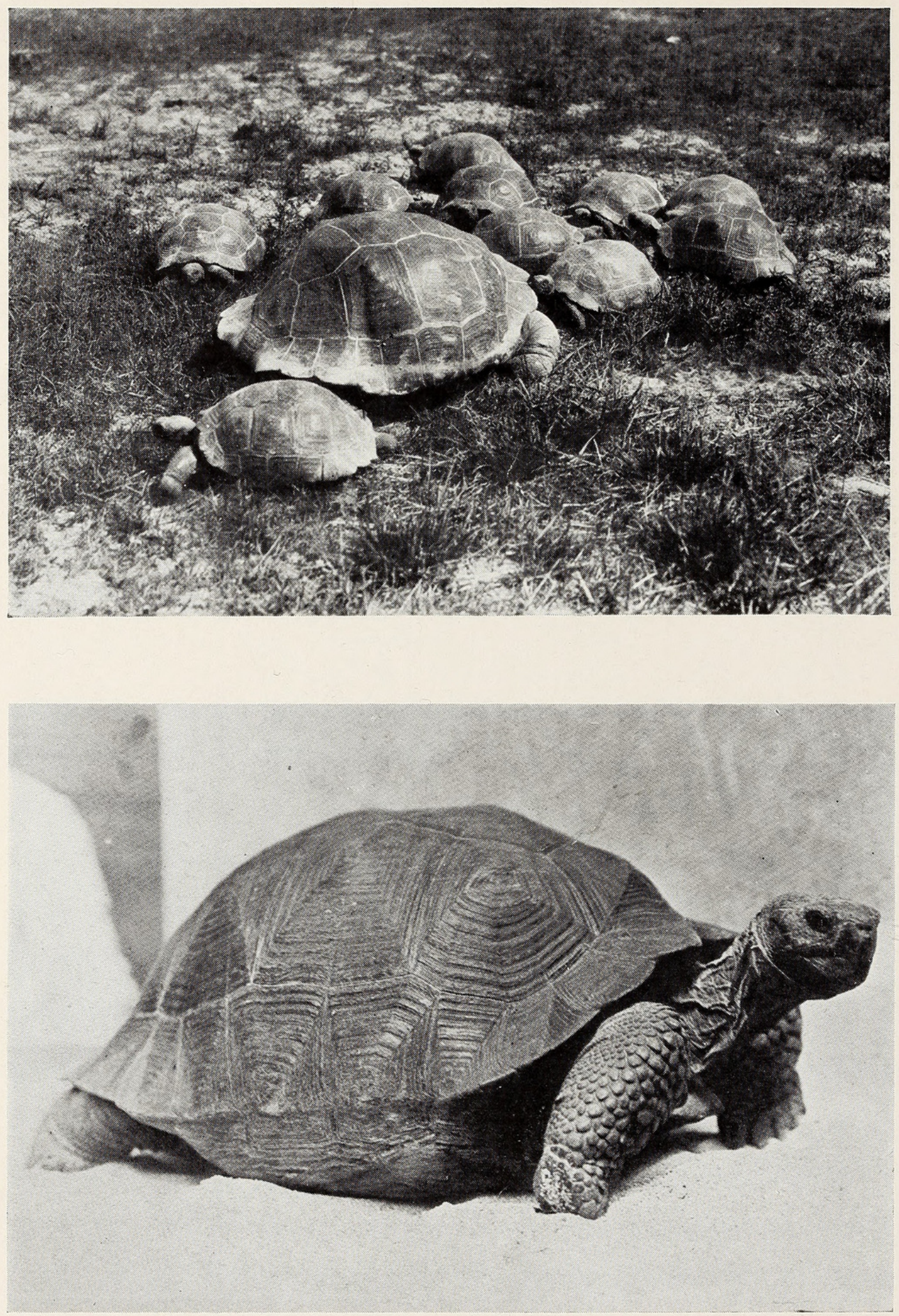

Fig. 364. Upper: Tortoise No. 104 (largest). Weight 71 pounds. About 10 years old. Rings on plates, 10. Fig. 365. Lower: Tortoise No. 187, Testudo porteri, Indefatigable Island, Galapagos. Same size as No. 190, with same number of rings. Should be the same age, 12 years. 

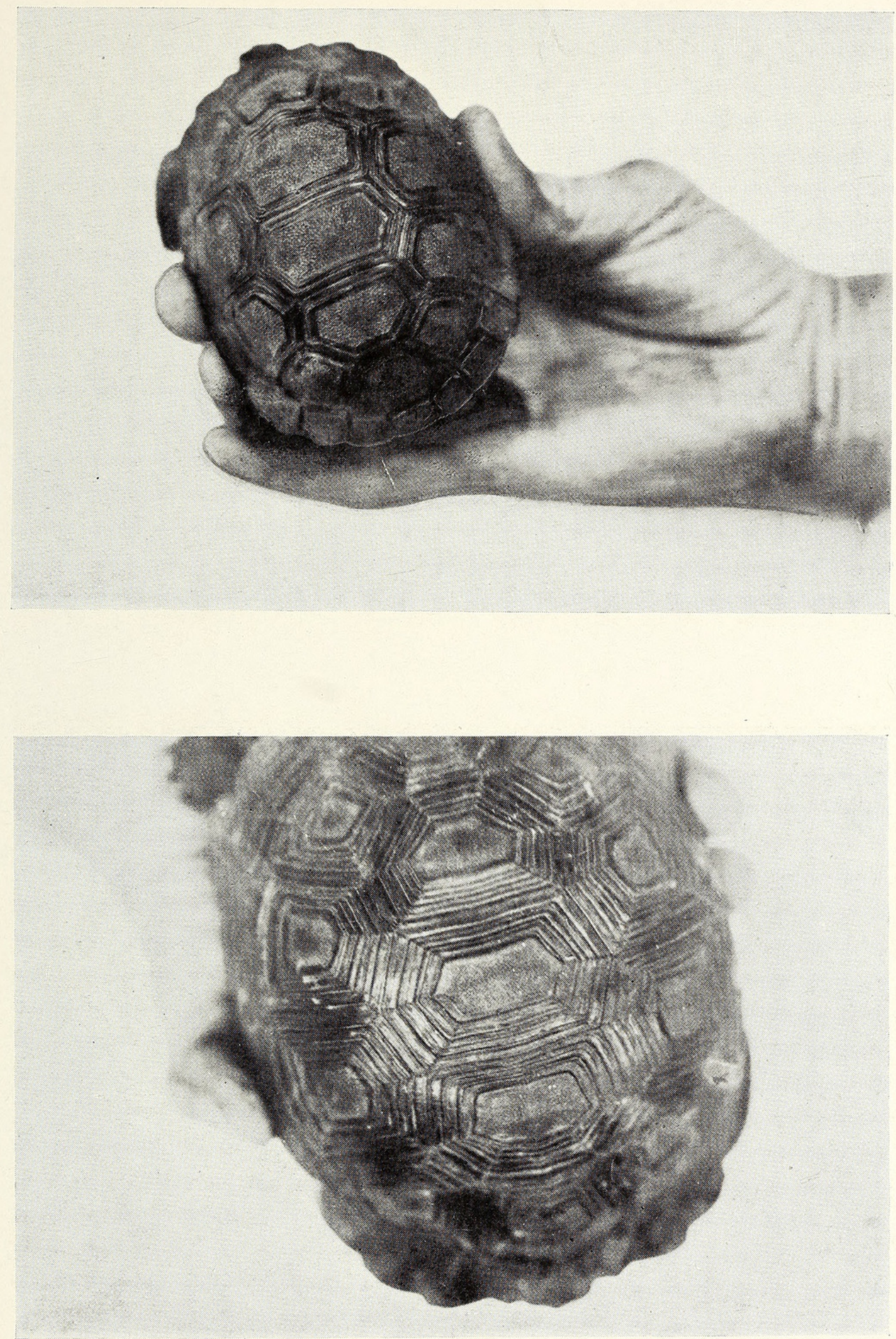

Fig. 366. Upper: Testudo vicina, with 2 growth rings on plates. Fig. 367. Lower: Testudo vicina (same as Fig. 366), but two years older, with 4 rings of growth on plates. 

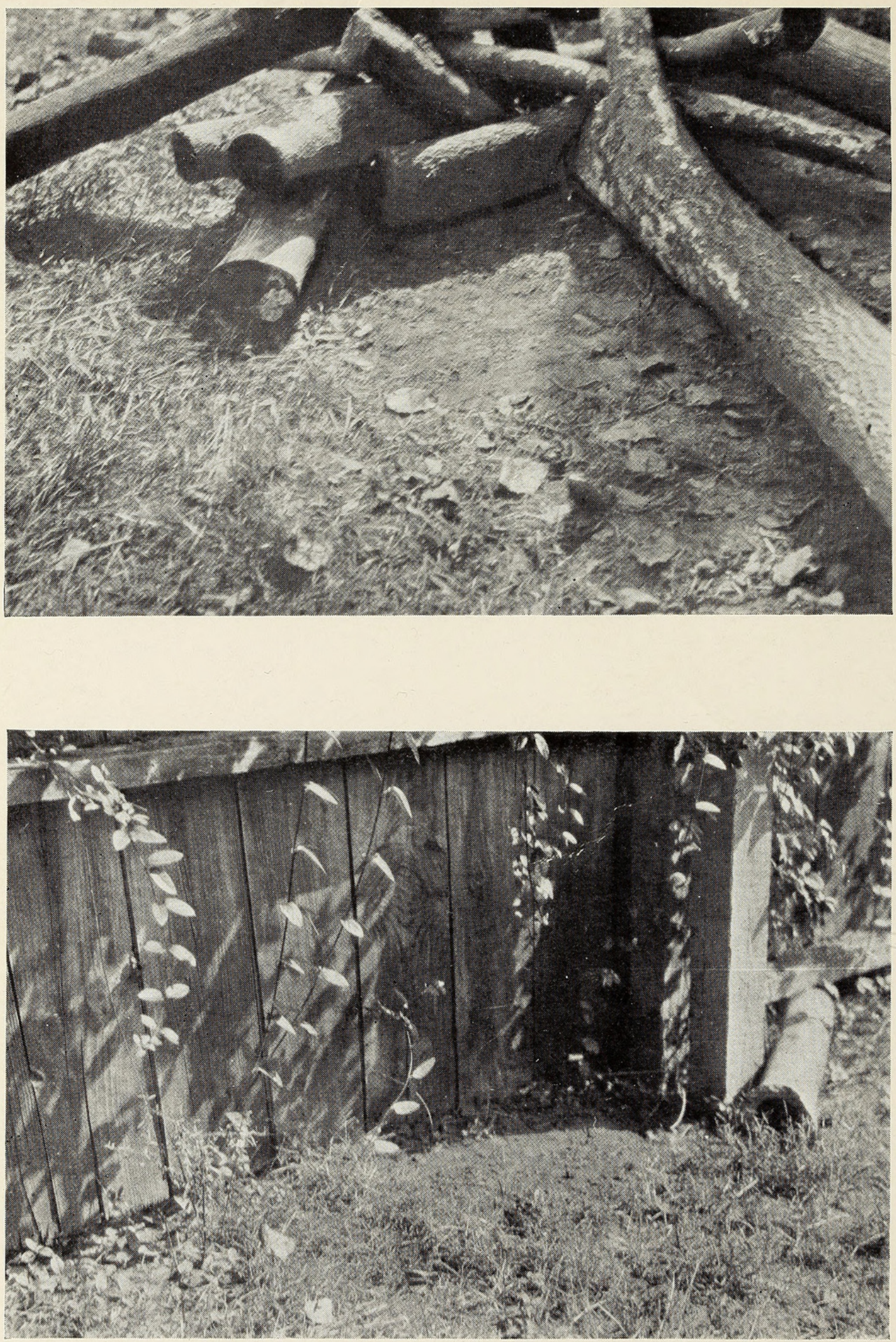

Fig. 368. Upper: Resting place of Tortoise No. 190 at night. Shows where the sod is scratched away. Fig. 369. Lower: Another night resting place, also shows where the tortoise scratched the sod away. 


\section{$2 \mathrm{BHL}$ Biodiversity Heritage Library}

Townsend, Charles Haskins. 1931. "Growth and age in the Giant Tortoise of the Galapagos." Zoologica : scientific contributions of the New York Zoological Society 9(13), 459-474. https://doi.org/10.5962/p.203753.

View This Item Online: https://www.biodiversitylibrary.org/item/208079

DOI: https://doi.org/10.5962/p.203753

Permalink: https://www.biodiversitylibrary.org/partpdf/203753

\section{Holding Institution}

Smithsonian Libraries

\section{Sponsored by}

Biodiversity Heritage Library

\section{Copyright \& Reuse}

Copyright Status: In Copyright. Digitized with the permission of the rights holder

Rights Holder: Wildlife Conservation Society

License: http://creativecommons.org/licenses/by-nc/3.0/

Rights: https://www.biodiversitylibrary.org/permissions/

This document was created from content at the Biodiversity Heritage Library, the world's largest open access digital library for biodiversity literature and archives. Visit BHL at https://www.biodiversitylibrary.org. 